\title{
Vegetation analysis of tree communities at some forest patches in North Sulawesi, Indonesia
}

\author{
MUSTAID SIREGAR ${ }^{\star}$, HENDRA HELMANTO, SRI ULIE RAKHMAWATI \\ Research Center for Plant Conservation and Botanic Gardens (Bogor Botanic Gard ens), Indonesian Institute of Sciences. Jl. Ir. H. Juanda No. 13 Bogor \\ 16122, West Java, Indonesia. Tel./fax.: +62-251-8322-187, †email: mustaid_s@yahoo.co.id
}

Manuscript received: 21 January 2018. Revision accepted: 11 February 2019.

\begin{abstract}
Siregar M, Helmanto H, Rakhmawati SU. 2019. Vegetation analysis of tree communities at some forest patches in North Sulawesi, Indonesia. Biodiversitas 20: 643-655. Deforestation has caused a decline in forest area in Indonesia. Now natural forests is left in the conservation areas while those outside conservation areas are narrow and fragmented. This study aims to analyze forest vegetation and conservation status of the species of trees in some forest patches in North Sulawesi. Diversity, structure and type of tree communities at five forest patches, namely in the villages of Bukaka, Garini and Lambak in East Bolaang Mongondow District, and Soyowan and Basaan villages in Southeast Minahasa District, North Sulawesi Province were studied using a point center quarter method. The total number of tree species $(\mathrm{dbh} \geq 10 \mathrm{~cm})$ across five patches is 84 species. The highest number of species is in Garini $(37$ species), followed by Lambak (25 species), Soyowan (19 species), Bukaka (10 species) and Basaan (7 species). The species diversity index also shows the same pattern with such species richness, but the dominance index demonstrates opposite trend. The highest evenness index $(E)$ is found in Bukaka $(E=0.9524)$, followed by Soyowan $(E=0.9061)$, Garini $(E=0.7873)$, Basaan $(E=0.7809)$ and Lambak $(E=0.7099)$. The most important tree species based on the Species Important Value (SIV) in Bukaka is Ficus sp. (SIV = 52.17), in Garini is Octomeles sumatrana (SIV = 25.73), in Lambak is Boehmeria cylindrica (SIV $=65.03$ ), both in Basaan and Soyowan is Dracontomelon dao with SIV of 96.87 and 46.46 respectively. The beta diversity analyzed based on species similarity index of Jaccard and Whittaker 's index shows a relatively large change in species composition from one location to another. The family of Moraceae, Malvaceae, Anacardiaceae, Annonaceae and Lauraceae are listed as the widest family with a relatively high population. The highest tree density is found in Bukaka $\left(721\right.$ trees ha $\left.^{-1}\right)$, followed by Lambak (482 trees ha $\left.{ }^{-1}\right)$, Basaan (439 trees ha-1), Garini $(292$ trees $\mathrm{ha}^{-1}$ ) and Soyowan $\left(164\right.$ trees ha $\left.^{-1}\right)$. The highest basal area is also found in Garini $\left(53.59 \mathrm{~m}^{2} \mathrm{ha}^{-1}\right)$, followed by Basaan $\left(51.62 \mathrm{~m}^{2} \mathrm{ha}^{-1}\right)$, Lambak $\left(30.74 \mathrm{~m}^{2} \mathrm{ha}^{-1}\right)$, Soyowan $\left(25.13 \mathrm{~m}^{2} \mathrm{ha}^{-1}\right)$ and Bukaka $\left(20.98 \mathrm{~m}^{2} \mathrm{ha}^{-1}\right)$. The results of Cluster analysis using data of species abundance indicate that the five research locations tend to form two types of tree communities. The first community consists of Garini, Soyowan, Lambak and Bukaka, while the second community is represented only by Basaan.
\end{abstract}

Keywords: East Bolaang Mongondow, forest patches, Southeast Minahasa, North Sulawesi, vegetation analysis

\section{INTRODUCTION}

Twenty years ago (April 20,1999) at a meeting of the World Commission on Forests and Sustainable Development, it was realized that the world's forests had been exploited to the point of crisis, and there were many changes in the function of the area which had previously been closed to mining, industrial, agriculture, plantations and settlements. In Borneo, the industrial sector of oil palm and timber plantations is the biggest cause of deforestation. In 2001 2017 , forest area fell by $14 \%$ (6.04 million ha), including 3.06 million ha of forest, which was eventually converted to industrial plantations (Gaveau et al. 2018). In 1973-2015 period an estimated 18.7 million ha of Borneo's old-growth forest were cleared. Industrial plantations (oil-palm and pulpwood) expanded by 9.1 million ha. Approximately 7.0 million ha $(76.1 \%)$ of the total plantation area in 2015 was old-growth forest in 1973, of which 4.5-4.8 million ha (24-26\% of Borneo-wide deforestation) were planted within five years of forest clearance (Gaveau et al. 2016). It is not surprising that the total forest area in Indonesia continues to decline from year to year. Hansen et al. (2013) released a figure of more than $20,000 \mathrm{~km}^{2}$ (2 million ha) of
Indonesian forests lost during the period 2011-2012, an increase compared to the 2000-2003 period of less than $10,000 \mathrm{~km}^{2}$ (1 million ha). Other data was submitted by Forest Watch Indonesia (2011) which states that Indonesia lost 15.16 million hectares of forest with a deforestation rate reaching 1.51 million hectares per year during the period 2000-2009. The latest data based on the calculation of the Directorate General of Planology, Indonesia's deforestation rate for the 2014-2015 period amounted to 1.09 million hectares and decreased in the 2015-2016 period to 0.63 million hectares. But the definition of deforestation is still a debate at the international level, because it impacts on the calculation of deforestation (Arumingtyas 2018). Now natural forests are left in the conservation areas while those outside conservation areas are narrow and fragmented. Patches of forest outside conservation areas are generally found in other designation areas that have not been utilized, in customary forests and in areas that are intentionally conserved by communities as source of water, and have sacred values and other ecological benefits. Forest cover in Indonesia in 2016 was $89,848,200$ hectares, consisting of primary forest $(46,020,600 \mathrm{ha})$ and secondary forest $(43,827,600 \mathrm{ha})$. As 
much as $92.7 \%$ are located in forest estate (Kawasan Hutan) either as production forests, limited production forests, watershed protection forests and conservation areas (e.g. national park, wildlife reserve) while the rest $(7.3 \%)$ is located in nonforest estate land (Area Penggunaan Lain/APL) (Ministry of Environment and Forestry 2016).

Sulawesi is one of the fastest growing islands, especially in mining and agricultural sectors. Consequently, the island ranks third after Kalimantan and Sumatra in terms of deforestation rates. The latest data published by the Ministry of Environment and Forestry (2016) shows that deforestation in Sulawesi in 2015-2016 reached 85,414.6 ha, increasing 50\% from 2014-2015 which was 56,940.3 ha. The largest deforestation occurred in conservation areas which reached $64,406.4$ ha $(75.4 \%)$ while the rest $(24.6 \%)$ is in the other designation areas. Viewed from forest condition, the largest deforestation occurred in secondary forest which reached $67,497.5$ ha $(79.02 \%)$, while in primary forest it was $17,917.1$ ha $(20.98 \%)$. Primary forest cover in Sulawesi in 2016 was left with 3,892,900 ha, while secondary forest was 5,328,300 ha.

North Sulawesi is the province in Sulawesi with the least forest cover with only 555,300 ha, covering 243,000 ha of primary forest and 312,300 ha of secondary forest. Among those forest cover, 507,800 ha is inside conservation areas and the remaining of 47,500 in the other designation areas. Nonetheless, the extent of deforestation in this region is quite worrying. In 2015-2016 deforestation in North Sulawesi was recorded at 2,352.5 ha, an increase of $1,307.6$ ha $(125.1 \%)$ compared to deforestation in 2014 2015. The largest deforestation occurred in conservation areas which reached $1,838.5$ ha $(78.2 \%)$, while in the other designation areas it was 514 ha $(21.8 \%)$. Deforestation in secondary forests reached $1,584.6$ ha $(67.4 \%)$, while in primary forest 768 ha $(32.6 \%)$.

Forest cover that tends to decrease does not only reduce the biodiversity level, but also affects global climate and other natural disasters. Forest patches outside conservation areas are among those that are particularly vulnerable to degradation and deforestation, especially in the other designation areas and forests that are not protected by customary/local laws. In North Sulawesi, forest patches in a small area $(<10 \mathrm{ha})$ are common. Usually, it is located in the middle of a stretch of people's gardens, the banks of rivers and lakes, small hills and on the sidelines or valley of hills as a gallery forest.

In order to determine the condition of stands including species diversity, structure and type of community, an analysis of tree vegetation in several forest patches found in East Bolaang Mongondow and Southeast Minahasa Districts, North Sulawesi Province was carried out. This vegetation data is very important as a basis for the use and conservation of biodiversity and other natural resources (Kartawinata 2013).

\section{MATERIALS AND METHODS}

\section{Study site}

The study was conducted from July 26 to August 14, 2017 in natural forest areas including Kotabunan
Subdistrict, East Bolaang Mongondow District and Ratatotok Subdistrict, Southeast Minahasa District, North Sulawesi Province (Figure 1). Natural forests in these regions have been transformed into plantations, secondary forests and shrubs. Primary forests that are relatively undisturbed are generally found in the form of forest patches on small hills and in crevices of hills. The largest extent of forest in East Bolaang Mongondow District is in Linelean tropical forest area where there is Garini waterfall. Five patches of forest that still have tree vegetation with different environmental characteristics were selected for research, namely: (i) Bukaka Forest (N $00^{\circ} 51^{\prime} 59.1^{\prime \prime}$; E $124^{\circ} 36^{\prime} 43.5^{\prime \prime}$ ) at an elevation of $400 \mathrm{~m}$ asl. located in Bukaka Village, Kotabunan Subdistrict, East Bolaang Mongondow District. (ii) Garini Forest (N 00 52 ' 33.9 "; E $124^{\circ} 36$ 31.4") at an elevation of 500-625 m asl. located in Bukaka Village, Kotabunan Subdistrict, East Bolaang Mongondow District. (iii) Lambak Forest $\left(\mathrm{N} 00^{\circ}\right.$ $54^{\prime} 15^{\prime} 3^{\prime \prime}$; E $\left.124^{\circ} 39^{\prime} 16.0^{\prime \prime}\right)$ at an elevation of $527 \mathrm{~m}$ asl. located in Buyat I Village, Kotabunan Subdistrict, East Bolaang Mongondow District. It is a patch of forest surrounded by fields, mixed gardens and shrubs. (iv) Soyowan Forest (N 00 54 57.8“' E $124^{\circ} 42^{\prime} 39.3^{\prime \prime}$ ) at an elevation of $352 \mathrm{~m}$ asl. located in Soyowan Village, Ratatotok Subdistrict, Southeast Minahasa District. It is a gallery forest on hillside worship. (v) Basaan Forest $\left({\mathrm{N} 00^{\circ}}^{\circ}\right.$ $53^{\prime} 54.6^{\prime \prime}$; E $\left.124^{\circ} 43^{\prime} 18.2^{\prime \prime}\right)$ at an elevation of $22 \mathrm{~m}$ asl. located in Basaan Village, Ratatotok Subdistrict, Southeast Minahasa District. Forests on small hills bordering residential and mixed gardens.

Two closest climate stations namely Bukaka and Soyowan were chosen to collect climatic data at the study sites. Rainfall and temperature data in both locations are presented in Figure 2. Based on the Köppen-Geiger climate classification, both locations are classified as Af. The annual rainfall in Bukaka is $2284 \mathrm{~mm}$, while in Soyowan is $2226 \mathrm{~mm}$. The average temperature are $22.8^{\circ} \mathrm{C}$ and, $24.3^{\circ} \mathrm{C}$ in Bukaka and Soyowan, respectively (Climate-Data.Org. 2018). The topography is hilly to mountainous. The geology in Bukaka, Garini and Lambak consist of Bilungala volcanic rock formations which are dominated by intermediate igneous rocks to acidic (bright), such as: diorite, granodiorite and granite. Basaan consists of Ratatotok limestone formations, while Soyowan is located in the northern part of Ratatotok limestone formation which borders the Bilungala volcanic rock formation (Kalangi et al. 2009).

\section{Vegetation sampling}

The study was conducted using point center quarter method (Mueller-Dombois and Ellenberg 1974). A total of 42 points were sampled from five locations, respectively: Garini 20 points, Lambak 10 points, Soyowan 6 points, Bukaka 3 points and Basaan 3 points. Sampling was stopped if straight direction of the transect no longer found individual trees or was only covered with shrubs or mixed gardens. In Garini, sampling started from the edge of the forest towards the Garini waterfall. The $\mathrm{X}$ axis at each site pointed north-south $\left(0^{\circ}-180^{\circ}\right)$ and $\mathrm{Y}$-axis pointed east-west direction $\left(90^{\circ}-270^{\circ}\right)$ with distance between the center points 
was $20 \mathrm{~m}$. The closest tree in each quadrant was measured trunk diameter at breast height (dbh), total height and distance to the center of the quadrant. Leaf specimens were taken for identification purposes.

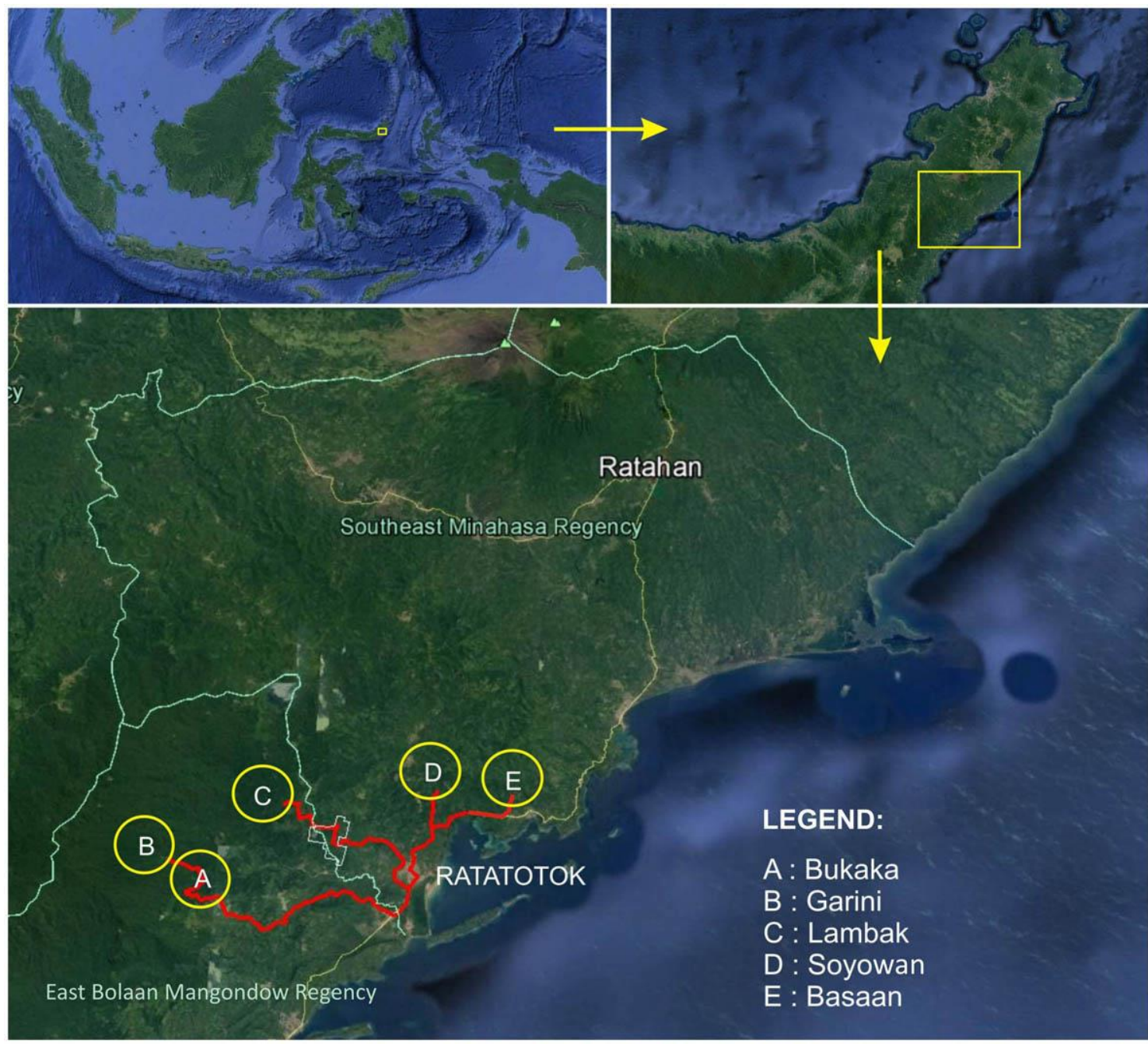

Figure 1. Map of research location in East Bolaang Mongondow District (Bukaka, Garini, Lambak) and Southeast Minahasa District (Soyowan, Basaan), North Sulawesi Province, Indonesia
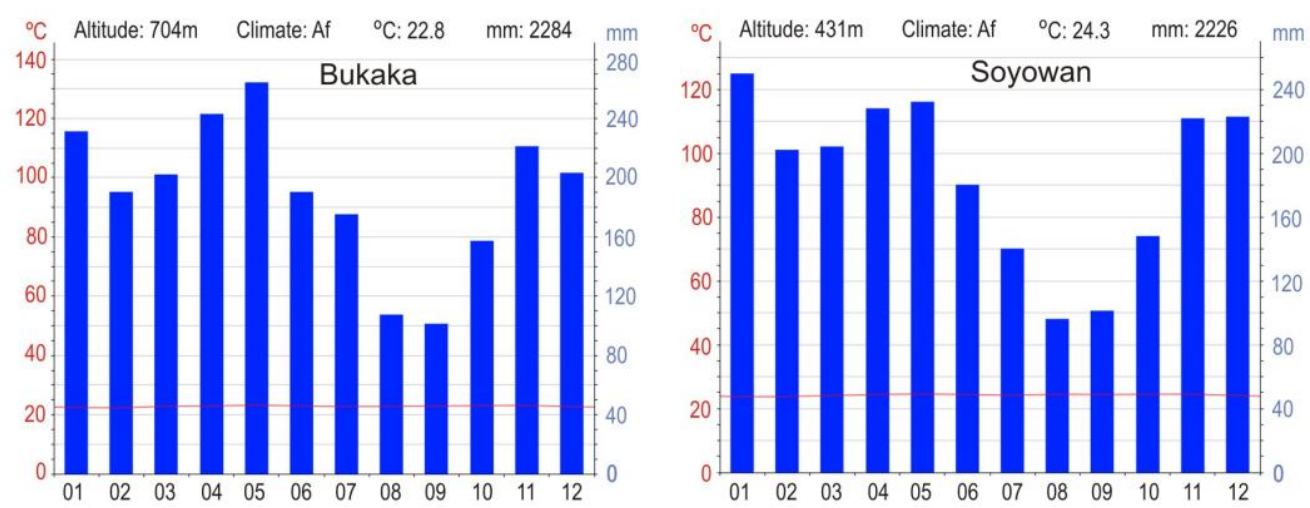

Figure 2. Rainfall and temperature at the research locations. A Bukaka, East Bolaang Mongondow District, B. Soyowan, Bolaang Mongondow District, North Sulawesi Province, Indonesia (source: climate-data.org. 2018) 


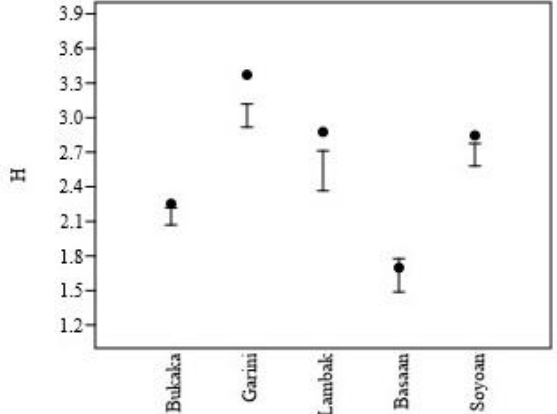

A

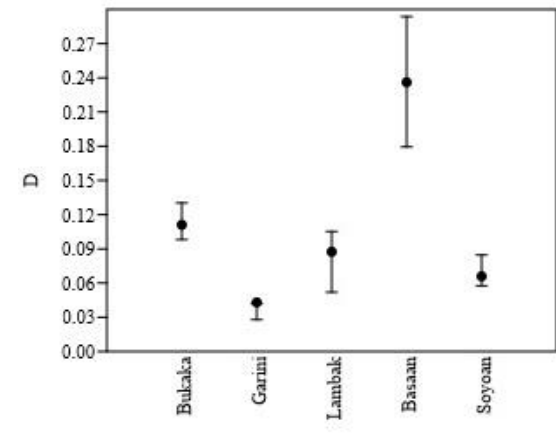

B

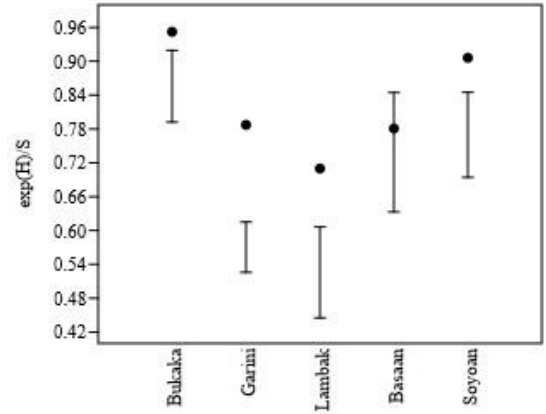

C

Figure 3. A. Shannon-Wiener diversity index (H`), B. Dominance index (D), C. Species evenness index (expH/S) in each location of in North Sulawesi, Indonesia

\section{Data analysis}

Density and dominance of tree species at each location were calculated following the Mueller-Dombois and Ellenberg (1974) method. The absolute density (Dab) in each location was calculated using the formula: Dab = $100 /(\text { Dav })^{2}$, where Dab is absolute density or Density/100 $\mathrm{m}^{2}$, while Dav is the average distance of the entire tree to the center of the quadrant. The dominance or basal area absolute (Bab) was obtained from the multiplication of the average value of the basal area of the entire tree with the number of trees in one location.

Tree density level of each species (Di) in each location was calculated using the formula: $\mathrm{D} i=(\mathrm{D} i / q) \times \mathrm{Dab}$, where $(\mathrm{D} i / q)$ is the number of species $i$ divided by the number of quadrants in one location. The dominance or basal area of each species $(\mathrm{B} i)$ in each location is calculated by the formula $\mathrm{B} i=\operatorname{Dav} i \times \mathrm{Dab}$, where Davi is the average distance of species $i$ to the center point of the quadrant.

Level of importance of species in each location was calculated based on the species importance value (SIV) which is the aggregation of relative values of frequency, density and dominance. Frequency is the percentage of the number of points where a species found. Level of importance of family in each location was calculated using the method by Mori et al. (1983) based on the family importance value (FIV) which is aggregation of relative values of the number of species, density and dominance of each family.

Alpha diversity was analyzed based on ShannonWiener diversity index ( $\left.\mathrm{H}^{`}\right)$, evenness index (E) and dominance index (D), while beta diversity was assessed based on similarity index of Jaccard (ISj) and beta diversity index (Whittaker's index). Community type was determined based on the results of cluster analysis based on species abundance in each location. All of these analyzes used PAST software program (paleontological Statistics) version 3:04 (Hammer 2014).

\section{RESULTS AND DISCUSSION}

\section{Diversity}

Results of sampling data in five research locations show that there were 84 species of trees $(\mathrm{dbh} \geq 10 \mathrm{~cm})$ belong to 59 genera and 35 families. The highest number of species was found in Garini (37 species), followed by Lambak (25 species), Soyowan (19 species), Bukaka (10 species) and Basaan (7 species). The Shannon-Wiener diversity index $\left(\mathrm{H}^{\prime}\right)$ in each location also shows the same pattern. The highest value is in Garini ( $\left.\mathrm{H}^{\prime}=3.3720\right)$ which belongs to high category, followed by Lambak $\left(\mathrm{H}^{\top}=2.8760\right)$, Soyowan $\left(\mathrm{H}^{\top}=2.8460\right)$, Bukaka $\left(\mathrm{H}^{`}=2.2540\right)$, and Basaan $\left(\mathrm{H}^{\prime}=1.6990\right)$ which categorized as medium. On the contrary, the highest dominance index is found in Basaan $(\mathrm{D}=0.2362)$, followed by Bukaka $(\mathrm{D}=0.1111)$, Lambak $(\mathrm{D}=0.0875)$, Soyowan $(\mathrm{D}=0.0660)$ and Garini $(\mathrm{D}=$ $0.0431)$. In term of species evenness index (E), the highest value is found in Bukaka $(\mathrm{E}=0.9524)$, followed by Soyowan $(\mathrm{E}=0.9061)$, Garini $(\mathrm{E}=0.7873)$, Basaan $(\mathrm{E}=$ 0.7809) and Lambak $(\mathrm{E}=0.7099)$ (Figure 3).

The high dominance index in Basaan is mainly due to the abundance of Streblus ilicifolius with relative density of $41.7 \%$. Together with Dracontomelon dao, they dominate $58.3 \%$ of tree population in Basaan. In Garini, two most abundant species are Oreocnide integrifolia and Myristica elliptica which dominate the population of $17.5 \%$. Two most abundant species in Lambak are Boehmeria cylindrica and Cratoxylum sumatranum which control $35.0 \%$ of the tree population. Bukaka is dominated by Syzygium leucocladum and Ficus sp. which controls $33.3 \%$ of the tree population, while in Soyowan it is dominated by D. dao and Pterospermum javanicum which controls $25.0 \%$ of the tree population.

The important species based on species importance value (SIV) in each location can be seen in Table 1. The important species in Bukaka is Ficus sp. (SIV = 52.17), in Garini is Octomeles sumatrana ( $\mathrm{SIV}=25.73)$, in Lambak 
is $B$. cylindrica ( $\mathrm{SIV}=65.03$ ), in Basaan and Soyowan is D. dao with SIV of 96.87 and 46.46, respectively. Variations of the five most important species in across locations are relatively high. Only two species are among the five most important species in two different locations, namely D. dao in Basaan and Soyowan, and Cananga odorata in Bukaka and Garini.

Based on its basal area, the most dominant species in Bukaka is Litsea dilleniifolia with basal area of $3.87 \mathrm{~m}^{2}$ ha${ }^{1}$, in Garini is $O$. sumatrana $\left(7.56 \mathrm{~m}^{2} \mathrm{ha}^{-1}\right)$, in Lambak is $B$. cylindrica $\left(7.41 \mathrm{~m}^{2} \mathrm{ha}^{-1}\right)$, and in Basaan and Soyowan is $D$. dao (29.93 and $5.11 \mathrm{~m}^{2} \mathrm{ha}^{-1}$, respectively). In term of distribution of species based on frequency (RFi), the most widespread species of distribution in Bukaka are Ficus sp. and S. leucocladum who has an RF $i$ of $16.67 \%$. The most extensive species of distribution in Garini is $O$. integrifolia ( $\mathrm{RF} i=8.60 \%)$, in Lambak is B. cylindrica $(\mathrm{RF} i=18.42 \%)$, in Basaan are D. dao and S. ilicifolius with RF $i=22.22 \%$ and in Soyowan is D. dao ( $\mathrm{RF} i=13.64 \%)$.

Beta diversity based on the species similarity index across locations also has relatively low value. The highest similarity index (IS Jaccard) is shown between Garini and
Soyowan (ISj $=0.1200)$, followed by Lambak-Soyowan (ISj = 0.1000), Bukaka-Soyowan (ISj = 0.0741), GariniLambak (IS $j=0.0690)$, Soyowan-Basaan $(\mathrm{IS} j=0400)$, Lambak-Basaan (IS $j=0.0323$ ), Lambak-Bukaka $(\mathrm{IS} j=$ 0.0294), Garini-Basaan (IS $j=0.0233$ ) and Garini-Bukaka (IS $j=0.0217)$. Basaan and Bukaka have no similarities at all $(\mathrm{IS} j=0)$. To put into perspective, Mueller-Dombois and Ellenberg (1974) state that Jaccard similarity index above $50 \%(0.50)$ are considered as very large.

The result of beta diversity index based on Whittaker's index shows that changes in species composition from one location to another are also relatively high, indicated by the value of index that closes to one (Table 2). Locations that are relatively similar is between Garini and Soyowan, yet the index is still relatively large $(0.7857)$. Beta diversity index value ranges from 0 to 1 . The value of 0 means the minimum beta diversity, where there is no change in species composition from location 1 to location 2 . On the contrary, the value of 1 , or maximum beta diversity, means that species composition from location 1 to location 2 is totally different (Tothmeresz 2013).

Table 1. Relative density (RDi), relative dominance ( $\mathrm{RB} i$ ), relative frequency (RFi) and species importance value (SIV) of each species in each study site of North Sulawesi, Indonesia

\begin{tabular}{|c|c|c|c|c|c|}
\hline Species & Family & $\mathbf{R D} i$ & $\mathbf{R B} i$ & $\mathbf{R F i}$ & SIV \\
\hline \multicolumn{6}{|l|}{ Bukaka } \\
\hline Ficus sp. & Moraceae & 16.67 & 18.83 & 16.67 & 52.17 \\
\hline Syzygium leucocladum Merr. \& L.M.Perry & Myrtaceae & 16.67 & 6.76 & 16.67 & 40.09 \\
\hline Litsea dilleniifolia P.Y. Pai \& P.H. Huang & Lauraceae & 8.33 & 18.46 & 8.33 & 35.12 \\
\hline Ficus arfakensis King & Moraceae & 8.33 & 18.05 & 8.33 & 34.71 \\
\hline Cananga odorata (Lam.) Hook.f. \& Thomson & Annonaceae & 8.33 & 15.32 & 8.33 & 31.99 \\
\hline Melodinus cochinchinensis (Lour.) Merr. & Apocynaceae & 8.33 & 7.66 & 8.33 & 24.33 \\
\hline Pterospermum javanicum Jungh. & Malvaceae & 8.33 & 5.03 & 8.33 & 21.70 \\
\hline Piper aduncum L. & Piperaceae & 8.33 & 3.65 & 8.33 & 20.31 \\
\hline Pandanus sp. & Pandanaceae & 8.33 & 3.29 & 8.33 & 19.96 \\
\hline Tetracera scandens (L.) Merr. & Dilleniaceae & 8.33 & 2.95 & 8.33 & 19.62 \\
\hline \multicolumn{6}{|l|}{ Garini } \\
\hline Octomeles sumatrana Miq. & Datiscaceae & 6.25 & 14.10 & 5.38 & 25.73 \\
\hline Oreocnide integrifolia (Gaudich.) Miq. & Urticaceae & 10.00 & 6.47 & 8.60 & 25.07 \\
\hline Barringtonia racemosa (L.) Spreng. & Lecythidaceae & 6.25 & 8.76 & 5.38 & 20.39 \\
\hline Myristica elliptica Wall. & Myristicaceae & 7.50 & 3.16 & 6.45 & 17.11 \\
\hline Cananga odorata (Lam.) Hook.f. \& Thomson & Annonaceae & 5.00 & 6.82 & 4.30 & 16.12 \\
\hline Croton sp. & Euphorbiaceae & 2.50 & 11.08 & 2.15 & 15.73 \\
\hline Citronella moorei (F.Muell. ex Benth.) R.A.Howard & Cardiopteridaceae & 6.25 & 3.06 & 5.38 & 14.68 \\
\hline Horsfieldia costulata Warb. & Myristicaceae & 2.50 & 5.98 & 4.30 & 12.78 \\
\hline Ficus sp.1 & Moraceae & 2.50 & 7.12 & 2.15 & 11.77 \\
\hline Fontanesia sp. & Oleaceae & 3.75 & 3.63 & 3.23 & 10.60 \\
\hline Dracontomelon dao (Blanco) Merr. \& Rolfe & Anacardiaceae & 2.50 & 4.43 & 2.15 & 9.08 \\
\hline Euhporbiaceae 3 & Euphorbiaceae & 2.50 & 4.33 & 2.15 & 8.98 \\
\hline Ziziphus borneensis Merr. & Rhamnaceae & 3.75 & 1.90 & 3.23 & 8.88 \\
\hline Neonauclea glabra (Roxb.) Bakh.f. \& Ridsdale & Rubiaceae & 1.25 & 0.08 & 7.53 & 8.85 \\
\hline Talipariti tiliaceum (L.) Fryxell & Malvaceae & 3.75 & 0.52 & 3.23 & 7.50 \\
\hline Pometia pinnata J.R.Forst. \& G.Forst. & Sapindaceae & 1.25 & 0.77 & 5.38 & 7.40 \\
\hline Alstonia scholaris (L.) R. Br. & Apocynaceae & 2.50 & 2.72 & 2.15 & 7.37 \\
\hline Dictyoneura acuminata Blume & Sapindaceae & 1.25 & 3.43 & 1.08 & 5.75 \\
\hline Diospyros pentamera (F.Muell.) Woods \& F.Muell. & Ebenaceae & 1.25 & 3.09 & 1.08 & 5.42 \\
\hline Oreocnide rubescens (Blume) Miq. & Urticaceae & 2.50 & 0.72 & 2.15 & 5.37 \\
\hline Chionanthus ramiflorus Roxb. & Oleaceae & 2.50 & 0.70 & 2.15 & 5.35 \\
\hline Orophea sp. & Annonaceae & 2.50 & 0.51 & 2.15 & 5.16 \\
\hline Cryptocarya ferrea Blume & Lauraceae & 2.50 & 0.28 & 2.15 & 4.93 \\
\hline
\end{tabular}


Ficus magnoliifolia Blume

Uvaria chamae P.Beauv.

Euphorbiaceae 1

Euphorbiaceae 2

Parashorea malaanonan Merr.

Meliosma pinnata (Roxb.) Maxim.

Baccaurea racemosa (Reinw. ex Blume) Müll.Arg.

Gardenia sp.

Magnolia vrieseana (Miq.) Baill. ex Pierre

Licania sp.

Kopsia pauciflora Hook.f.

Mallotus cumingii Müll.Arg.

Syzygium lineatum (DC.) Merr. \& L.M.Perry

Dendrocnide stimulans (L.f.) Chew

\section{Lambak}

Boehmeria cylindrica (L.) Sw.

Cratoxylum sumatranum (Jack) Blume

Falcataria moluccana (Miq.) Barneby \& J.W.Grimes

Hibiscus tilliaceus $\mathrm{L}$.

Artocarpus elasticus Reinw. ex Blume

Cananga odorata (Lam.) Hook.f. \& Thomson

Litsea machilifolia Gamble

Glochidion candolleanum (Wight \& Arn.) Chakrab. \& M.Gangop.

Psychotria viridis Ruiz \& Pav.

Aglaia cumingiana Turcz.

Kibara coriacea (Blume) Hook. f. \& A. Thomps.

Dysoxylum gaudichaudianum (A.Juss.) Miq.

Unidentified 1

Ficus cumingii Miq.

Horsfieldia costulata Warb.

Oreocnide integrifolia (Gaudich.) Miq.

Moraceae

Myristica iners Blume

Saurauia pendula Blume

Saurauia leucocarpa Schltdl.

Litsea umbellata (Lour.) Merr.

Caryota no Becc.

Dracontomelon dao (Blanco) Merr. \& Rolfe

Macaranga gigantea (Rchb.f. \& Zoll.) Müll.Arg.

Kayu rupa (nama lokal)

\section{Basaan}

Dracontomelon dao (Blanco) Merr. \& Rolfe

Streblus ilicifolius (Vidal) Corner

Ficus sp.3

Bixa orellana $\mathrm{L}$.

Ficus tinctoria G.Forst.

Ficus sp.2

Ficus trichopoda Baker

\section{Soyowan}

Dracontomelon dao (Blanco) Merr. \& Rolfe

Pterospermum javanicum Jungh.

Neolamarckia cadamba (Roxb.) Bosser

Dictyoneura acuminata Blume

Thottea tomentosa (Blume) Ding Hou

Endiandra sp.

Meliaceae

Cananga odorata (Lam.) Hook.f. \& Thomson

Ardisia purpurea Reinw. ex Blume

Kayu bugis (nama lokal)

Heritiera longipetiolata Kaneh.

Canarium asperum Benth.

Diospyros cauliflora Blume

Euphorbiaceae 4

Myristica elliptica Wall.

Macaranga gigantea (Rchb.f. \& Zoll) Mull.Arg.

Oreocnide integrifolia (Gaudich.) Miq.

Oreocnide rubescens (Blume) Miq.

Mallotus floribundus (Blume) Müll.Arg.

Moraceae
Annonaceae
Euphorbiaceae
Euphorbiaceae
Dipterocarpaceae
Sabiaceae
Phyllanthaceae
Rubiaceae
Magnoliaceae
Chrysobalanaceae
Apocynaceae
Euphorbiaceae
Myrtaceae
Urticaceae

1.25

1.25

1.25

1.25

1.25

1.25

1.25

1.25

1.25

1.25

1.25

1.25

1.25

1.25

2.55

0.08

1.08

0.58

0.48

0.36

0.24

0.17

0.15

0.15

0.14

0.14

0.12

0.08

1.08

2.15

1.08

1.08

1.08

1.08

1.08

1.08

1.08

1.08

1.08

1.08

1.08

1.08

4.88

3.48

3.41

2.91

2.81

2.69

2.56

2.50

2.48

2.48

2.46

2.46

2.45

2.40

Urticaceae

Leguminosae

Malvaceae

Moraceae

Annonaceae

Lauraceae

Phyllanthaceae

Rubiaceae

Meliaceae

Monimiaceae

Meliaceae

Moraceae

Myristicaceae

Urticaceae

Moraceae

Myristicaceae

Actinidiaceae

Actinidiaceae

Lauraceae

Arecaceae

Anacardiaceae

Euphorbiaceae

22.50

12.50

24.11

18.42

65.03

2.50

7.50

12.04

14.23

13.16

2.63

7.89

5.26

$5.00 \quad 5.09$

$2.50 \quad 5.43$

2.50

2.50

2.50

2.50

2.50

2.50

2.50

2.50

2.50

2.50

2.50

2.50

2.50

2.50

2.50

2.50

2.50

2.50

2.50

5.17

3.77

3.77

2.41

2.41

2.41

2.41

1.92

1.92

1.42

1.36

1.11

1.03

1.00

1.00

1.00

0.89

0.84

0.79

2.63

2.63

2.63

2.63

2.63

2.63

2.63

2.63

2.63

2.63

2.63

2.63

2.63

2.63

2.63

2.63

2.63

2.63

2.63

2.63

19.37

17.84

15.35

10.56

10.31

8.90

8.90

7.55

7.55

7.55

7.55

7.06

7.06

6.55

6.49

6.24

6.16

6.13

6.13

6.13

6.02

5.97

5.92

Anacardiaceae

16.6

41.67

57.98

22.22

96.87

Moraceae

Moraceae

Bixaceae

Moraceae

Moraceae

Moraceae

8.33

8.33

18.07

74.53

$\begin{array}{lll}6.06 & 11.11 & 25.50\end{array}$

$\begin{array}{llll}8.33 & 3.76 & 11.11 & 23.20\end{array}$

$\begin{array}{llll}8.33 & 2.69 & 11.11 & 22.14\end{array}$

$\begin{array}{llll}8.33 & 0.80 & 11.11 & 20.25\end{array}$

Anacardiaceae

12.50

12.50

20.32

13.64

46.46

Malvaceae

Rubiaceae

Sapindaceae

Aristolochiaceae

8.33

4.17

4.17

Lauraceae

Meliaceae

Annonaceae

Primulaceae

Malvaceae

Euphorbiaceae

Ebenaceae

Euphorbiaceae

Myristicaceae

Euphorbiaceae

Urticaceae 
Table 2. Matrix of beta diversity of Whittaker's index based on species abundance in between two locations of North Sulawesi, Indonesia

\begin{tabular}{lcccc}
\hline Location & Bukaka & Garini & Lambak & Basaan \\
\hline Garini & 0.9575 & & & \\
Lambak & 0.9429 & 0.8710 & & \\
Basaan & 1.0000 & 0.9546 & 0.9375 & \\
Soyowan & 0.8621 & 0.7857 & 0.8182 & 0.9231 \\
\hline
\end{tabular}

Table 3. Thhree most important families based on Family Important Values (FIV) in each location of North Sulawesi, Indonesia

\begin{tabular}{llllll}
\hline Location & Family & $\mathbf{R D} \boldsymbol{f}$ & $\mathbf{R B} \boldsymbol{f}$ & $\mathbf{R S} \boldsymbol{f}$ & $\mathbf{F I V}$ \\
\hline Bukaka & Moraceae & 25.00 & 36.88 & 20.00 & 81.88 \\
& Lauraceae & 8.33 & 18.46 & 10.00 & 36.79 \\
& Annonaceae & 8.33 & 15.32 & 10.00 & 33.65 \\
Garini & Euphorbiaceae & 8.75 & 17.21 & 13.51 & 39.48 \\
& Urticaceae & 13.75 & 7.26 & 8.11 & 29.12 \\
& Myristicaceae & 10.00 & 9.15 & 5.41 & 24.55 \\
Lambak & Urticaceae & 22.50 & 24.11 & 4.00 & 50.61 \\
& Moraceae & 10.00 & 8.37 & 12.00 & 30.37 \\
Basaan & Hypericaceae & 12.50 & 12.04 & 4.00 & 28.54 \\
& Moraceae & 75.00 & 35.96 & 71.43 & 182.39 \\
& Anacardiaceae & 16.67 & 57.98 & 14.29 & 88.94 \\
Soyowan & Bixaceae & 8.33 & 6.06 & 14.29 & 28.67 \\
& Euphorbiaceae & 16.67 & 4.64 & 21.05 & 42.36 \\
& Anacardiaceae & 12.50 & 20.32 & 5.26 & 38.09 \\
& Malvaceae & 16.67 & 10.07 & 10.53 & 37.27 \\
\hline
\end{tabular}

Note: RDf: Relatif Density, RBf: Relatif Dominansi, RSf: Relatif number of species, FIV: Family importance value

Analysis at family level shows that Moraceae, Malvaceae, Anacardiaceae, Annonaceae and Lauraceae are the most widely distributed family, each of which is found in four locations with a relatively high population. Other families frequently found in abundance are Euphorbiaceae and Urticaceae which is found in three different locations. Family importance value (FIV) which is the sum of relative density ( $\mathrm{RD} f$ ), relative dominance $(\mathrm{RB} f)$ and relative number of species (RSf), shows that Moraceae appears as the most important family in Bukaka and Basaan with FIV of 81.8 and 182.39, respectively. Moraceae is also an important family after Urticaceae in Lambak. Euphorbiaceae is the most important family in Garini and Soyowan with FIV of 39.48 and 42.36, respectively (Table 3 ). Based on basal area, the most dominant family in Bukaka is Moraceae with basal area of $7.74 \mathrm{~m}^{2} \mathrm{ha}^{-1}$, in Garini is Euphorbiaceae $\left(9.22 \mathrm{~m}^{2} \mathrm{ha}^{-1}\right)$, in Lambak is Urticaceae $\left(7.85 \mathrm{~m}^{2} \mathrm{ha}^{-1}\right)$ and in Basaan and Soyowan is Anacardiaceae with basal area of 29.93 and $0.20 \mathrm{~m}^{2} \mathrm{ha}^{-1}$, respectively.

\section{Forest structure}

The highest tree density is found in Bukaka with 721 trees ha $^{-1}$, followed by Lambak (482 trees ha-1), Basaan (439 trees ha-1), Garini (292 trees ha ${ }^{-1}$ ) and Soyowan (164 trees $\left.\mathrm{ha}^{-1}\right)$. In term of basal area, the largest total basal area is found in Garini (53.59 $\mathrm{m}^{2} \mathrm{ha}^{-1}$ ), followed by Basaan (51.62 $\left.\mathrm{m}^{2} \mathrm{ha}^{-1}\right)$, Lambak (30.74 $\left.\mathrm{m}^{2} \mathrm{ha}^{-1}\right)$, Soyowan (25.13 $\left.\mathrm{m}^{2} \mathrm{ha}^{-1}\right)$ and Bukaka $\left(20.98 \mathrm{~m}^{2} \mathrm{ha}^{-1}\right)$. The average basal area per tree is also the largest in Garini $\left(0.1833 \mathrm{~m}^{2}\right)$, but Soyowan ranks second $\left(0.1535 \mathrm{~m}^{2}\right)$, then Basaan $(0.1177$ $\left.\mathrm{m}^{2}\right)$, Lambak $\left(0.0638 \mathrm{~m}^{2}\right)$ and Bukaka $\left(0.0291 \mathrm{~m}^{2}\right)$. These results suggest that tree density in Garini is relatively low, but the trees in there have larger average $\mathrm{dbh}(40.6 \mathrm{~cm})$. Similar result is also found at Soyowan. In contrast, tree density in Bukaka is high, but the average dbh is smaller $(18.1 \mathrm{~cm})$. The average dbh in Basaan is $30.8 \mathrm{~cm}$, whereas in Lambak is $26.1 \mathrm{~cm}$.

The distribution of dbh classes in five research locations resembles a letter ' $J$ ' inverted shape. Trees are abundant in small $\mathrm{dbh}$ classes and the number of individuals is reduced in larger dbh classes. The shape of this curve is the characteristic of tropical forests (Hartshon 1980, Proctor et al. 1983, Whitmore 1986; Abdulhadi et al. 1991, Kartawinata et al. 2004, Aigbe and Omokhua 2014), implying that tree regeneration going well (Priatna et al. 2006, Suwardi et al. 2013). Bukaka seems to only be inhabited by small trees with dbh less than $30 \mathrm{~cm}$. On the other hand, Soyowan is dominated by large trees with trees dbh above $40 \mathrm{~cm}$ comprise $46 \%$ of stands, while medium trees (dbh 20-40 cm) slightly decrease comprising 33\%, and trees with dbh $10-20 \mathrm{~cm}$ only comprise $21 \%$ of stands. A similar pattern is also found in Garini which shows abundant number of trees in large $\mathrm{dbh}(\mathrm{dbh}>40 \mathrm{~cm})$ and medium (dbh $20-40 \mathrm{~cm}$ ) which is $36 \%$ each, while trees with small dbh (dbh 10-20 cm) comprise of $28 \%$. Lambak forest is generally dominated by medium-sized trees (dbh $20-40 \mathrm{~cm}$ ), which is as much as $50 \%$, whereas in Basaan the trees dbh classes are in balance with medium (dbh 20$40 \mathrm{~cm}$ ) and small (dbh $10-20 \mathrm{~cm}$ ) comprise $42 \%$ of stands (Figure 4).

The biggest tree in Garini is Croton sp. with $108 \mathrm{~cm}$ in $\mathrm{dbh}$. Other species that have dbh of more than $90 \mathrm{~cm}$ are $O$. sumatrana, Barringtonia racemosa, Horsfieldia costulata and $C$. odorata. The largest tree in Soyowan is Dictyoneura acuminata with dbh of $75.0 \mathrm{~cm}$ and Thottea tomentosa with dbh of $73.0 \mathrm{~cm}$. In Basaan, the largest tree is $D$. dao with $\mathrm{dbh}$ of $98.0 \mathrm{~cm}$. Other species generally have dbh no more than $60 \mathrm{~cm}$. The largest tree found in Lambak is even smaller, only Falcataria moluccana which has $68.0 \mathrm{~cm}$ $\mathrm{dbh}$, even in Bukaka the largest is only $28.6 \mathrm{~cm}$ owned by L. dilleniifolia.

The vertical structure of the forest analyzed based on tree height generally shows the highest density in canopy height classes of 10.0-19.9 m. This pattern is found in Bukaka, Garini, Lambak and Basaan, while in Soyowan the highest density is found in the high canopy class 20.0-29.9 m (Figure 5). 


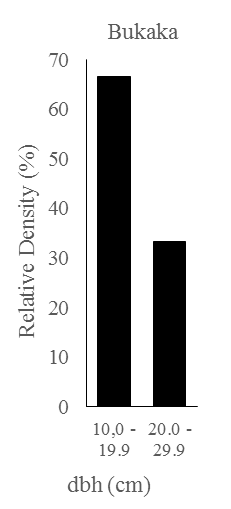

$\mathbf{A}$

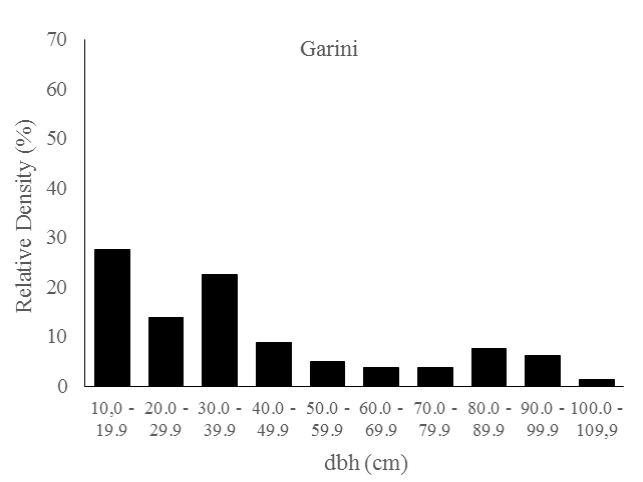

B

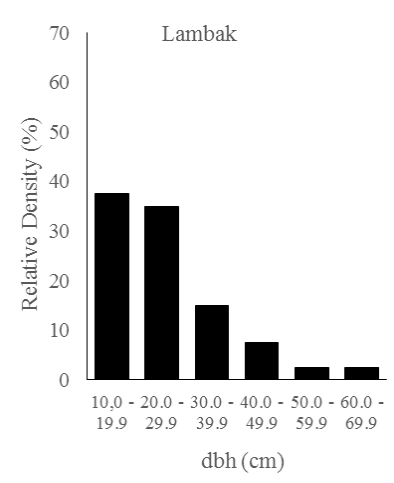

C

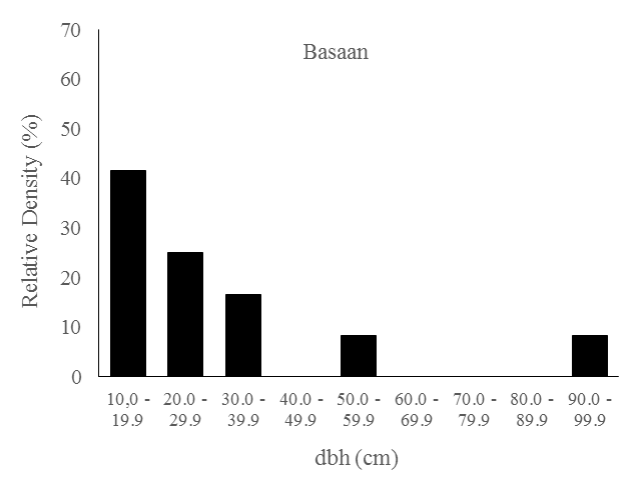

D

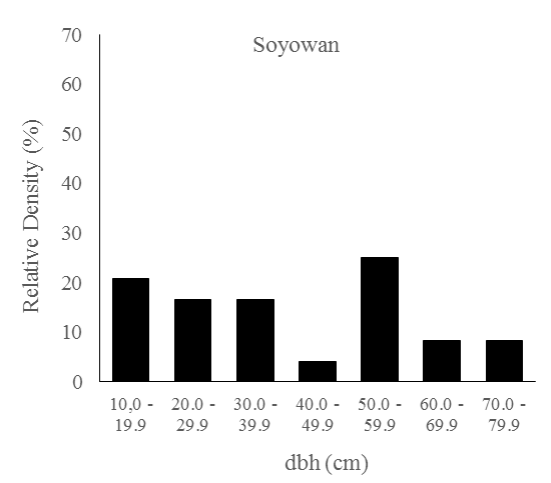

$\mathbf{E}$

Figure 4. Distribution of individual trees based on dbh classes in each location of North Sulawesi, Indonesia. A. Bukaka, B. Garini, C. Lambak, D. Basaan, E. Soyowan

The canopy layer in Garini tends to be evener. The upper layers (30.0-39.9 m) are inhabited by Citronella moorei, D. acuminata, Diospyros pentamera, Ficus magnoliifolia, H. costulata, M. elliptica, O. sumatrana, Oreocnide rubescens and Pometia pinnata with emergent trees of Barringtonia racemose, $C$. odorata, $D$. dao and $O$. sumatrana. In the middle layer (20.0-29.9 m), among others, are inhabited by Alstonia scholaris, Magnolia vrieseana, O. integrifolia, Ziziphus borneensis and species that also inhabit the upper layers such as B. racemose, $C$. odorata, C. moorei and M. elliptica. In the lower layer $(10.0-19.9 \mathrm{~m})$ is mainly inhabited by $O$. integrifolia, Talipariti tiliaceum, B. racemose, Chionanthus ramiflorus, Cryptocarya ferrea, Dendrocnide stimulans and young trees of the upper layers.

In Soyowan, the densest layer is at canopy heights 20.029.9 m, being inhabited by Neolamarckia cadamba, D. dao, Heritiera longipetiolata, Ardisia purpurea, $P$. javanicum and T. tomentosa. Emergent species with height above $30 \mathrm{~m}$ include D. acuminata and Endiandra sp., whereas in the lower layers of canopy are inhabited by $O$. integrifolia, Diospyros cauliflora, Canarium asperum, Mallotus floribundus, M. elliptica and secondary forest species, Macaranga gigantea.
The density of tree canopies in Lambak and Basaan drops dramatically as the tree height class rises. The emergent trees comprise no more than $10 \%$ of existing stands. Even in Bukaka, the tallest tree is only $18 \mathrm{~m}$, which is Ficus arfakensis. The vertical structure of the forest in Lambak and Basaan is relatively similar. The top layer of the canopy (30.0-39.9 m) in Lambak is occupied by Psychotria viridis and $C$. odorata. In the middle layer (20.0-29.9 m) is occupied by Aglaia cumingiana, $B$. cylindrical, $C$. sumatranum, Dysoxylum gaudichaudianum, $F$. moluccana, $P$. viridis and $C$. odorata. In the lower layer (10.0-19.9 m), B. cylindrical and C. sumatranum are still abundant and mixed with other species. As many as $76 \%$ of the tree species found in Lambak inhabit the bottom layer. Two species of the upper layers ( $P$. viridis and $C$. odorata) are not found in the lower layers.

In Basaan, the top layer of the canopy $(30.0-39.9 \mathrm{~m})$ is inhabited by $D$. dao . This species is also prominent in the middle layer (20.0-29.9 m) together with Ficus sp. Species from Moraceae family appear to dominate the lower layers such as S. ilicifolius, Ficus tinctoria and Ficus trichopoda. Some young $D$. dao species are also found in the lower layers. 


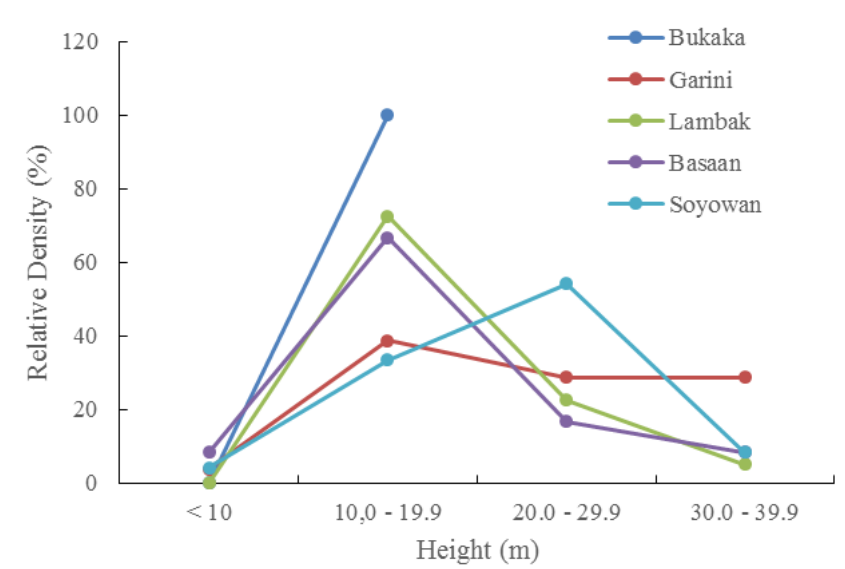

Figure 5. Individual distribution based on tree height class in each locations of North Sulawesi, Indonesia

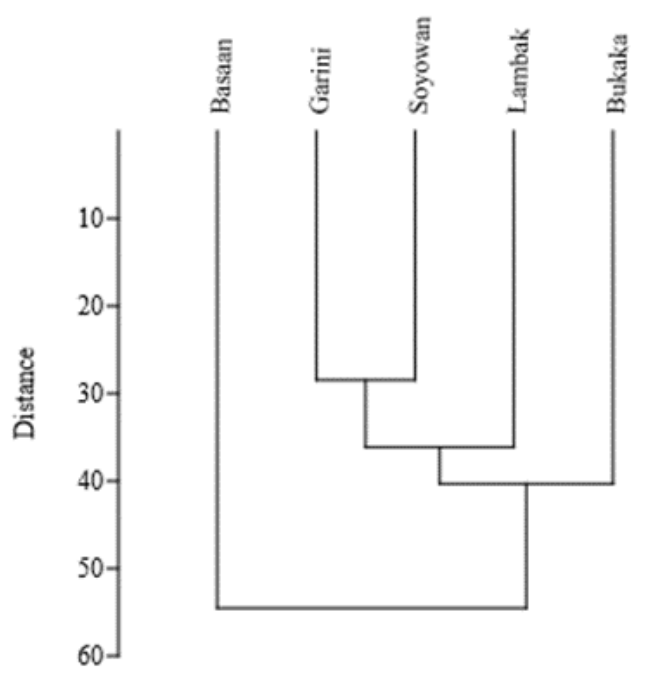

Figure 6. Dendrogram results of cluster analysis based on species abundance in each location of North Sulawesi, Indonesia

\section{Community type}

The results of cluster analysis presented in the form of dendrogram show that the five research locations tend to form two types of communities with a distance of 55 (Figure 6). The first community consists of Garini, Soyowan, Lambak and Bukaka, while the second community is represented only by Basaan. Based on the variation of composition of stands in across locations, it is likely that differentiator species in Basaan is S. ilicifolius which has an abundance of 183 trees $\mathrm{ha}^{-1}$ and is not found in the other locations. Other species are Bixa orellana, Ficus tinctoria, F. trichopoda with a smaller density of 37 trees $\mathrm{ha}^{-1}$. Two relatively similar locations are Garini and Soyowan which form group at a distance of 28 . Both locations are marked by the presence of different species of O. integrifolia, M. elliptica, C. odorata, D. dao, O. rubescens and D. acuminata.

\section{Discussion}

In regard to the altitude which ranges between of 22 and $625 \mathrm{~m}$ asl., the forest in the research locations is classified as lowland tropical forest while referring to the criteria of vegetation type by Kartawinata (2013), such forest belongs to dry lowland vegetation group. As there is no dominance of Dipterocarpaceae family as found in Kalimantan and Sumatra (Riswan 1987, Yusuf 2003, Simbolon et al. 2005, Priatna et al. 2006, Kartawinata 2013), therefore the forest in the study sites can be inferred as non-dipterocarp lowland forest group. The only species of Dipterocarpaceae recorded is Parashorea malaanonan, which is in Garini with dbh of $30 \mathrm{~cm}$ and height of $15 \mathrm{~m}$.

Species variations in five research sites are quite high, as can be seen from the small similarity index (IS Jaccard) and the beta diversity index (Whittaker's index) which close to one. Nonetheless, the forests in Garini, Soyowan, Lambak and Bukaka indicate under the same community type groups since the cluster analysis demonstrates to form a distinct group at a distance 55 that is different from Basaan (Figure 6). Environmental factors especially climate (e.g. temperature and humidity) and soil greatly affect the structure, species composition and distribution of vegetation geography (Tilman 1988; Pausas and Carreras 1995; Pausas and Austin 2001; Kartawinata 2013). Grubb (1987) found a positive relationship between tree species richness and soil fertility, but in another study Wright (1992) stated that soil fertility only affects the composition of herbaceous species and not on trees. Pausas and Carreras (1995) found that bedrock types influence the composition of understorey species in pine forests. Various research results also report that rainfall factors greatly affect species richness and composition of vegetation (Richerson and Lum 1980; Knight et al. 1982; Gentry 1988; Wright 1992; O'Brien 1993).

Rainfall factors at the study site may be negligible considering that two closest climate stations show relatively not much different measures (Figure 2). Habitat factors, especially soil and geology, might be the most influential on species composition in each study site. The geology in Garini, Soyowan, Lambak and Bukaka consists of Bilungala volcanic rock formations which are dominated by intermediate to acidic igneous (bright), while in Basaan it consists of Ratatotok limestone formation (Kalangi et al. 2009). The karst area (as found in Basaan) is a complex type of habitat with a thin layer of soil where plants can reach rocks that grow through rock slits (Toure and Ge 2014). Water holding capacity and soil fertility tend to be low with nickel, magnesium and other metals contained which can be toxic to plants, so the vegetation tends to be sparse or stunted and contains different species of other substrates (Corlett 2005).

On the map published by Kalangi et al. (2009), Soyowan is still included in the Ratatotok limestone formation, but the physical appearance in the field shows similarities with Garini, Lambak and Bukaka. Prominent limestone in Soyowan is rarely present as is the case in Basaan. There is a possibility that Soyowan is a transition from Bilungala volcano rock formations and the Ratatotok limestone. In addition, Soyowan forest is located in a 
valley area flanked by two hills covered with vegetation of shrubs and people's gardens. In parts of the valley generally, sedimentation rate and water content in the soil tend to be higher than in the slope (Siregar 2017). Basaan is a small hill that consists of limestone appearing on the surface of the ground and the edges of steep cliffs with thin soil layer. This difference in habitat characteristics is likely to have caused the composition of species in Basaan to be very different from other locations (Pausas and Carreras 1995; Corlett 2005).

Results of cluster analysis show that at a distance of 40 Bukaka forests demonstrate different community types with Garini, Soyowan and Lambak (Figure 6). It is not known exactly what causes the species in Bukaka to be different from other locations, even with nearby Garini. The only species recorded in Bukaka forest which are also found in Garini, Lambak and Soyowan is C. odorata. The striking difference in Bukaka is likely the higher level of interference. Presumably, this disturbance factor also plays a role in influencing species composition due to the number of tree species being cut. It's location on the side of the road and in vicinity of people's gardens and shrubs causes Bukaka forest to be susceptible to human disturbances. The trees appear to be in young stage as shown in stem diameter distribution (Figure 4) and the tree height (Figure 5). The forest in Bukaka is recorded to have the highest density (721 trees ha $\left.{ }^{-1}\right)$, but the total basal area is the lowest $\left(20.98 \mathrm{~m}^{2} \mathrm{ha}^{-1}\right)$ with the smallest average dbh $(18.1 \mathrm{~cm})$. The presence of Piper aduncum as a pioneer species that often grows in disturbed forests, on the edges of forests or open spaces (Global Invasive Species Database 2018) further strengthens this assumption.

Based on the phytogeographic zone, Indonesia, Brunei Darussalam, Philippines, Malaysia, Papua New Guinea, Singapore and Timor Leste including the Malesia region which has a distinctive flora that is different from the surrounding region. The Malesia region is divided into three phytogeographic provinces, namely (i) West Malesia, which includes the Malay Peninsula, Sumatra, Borneo and Philippines, (ii) East Malesia which includes Sulawesi, Maluku and Papua, and 3) Southern Malesia, which includes Java, Madura, Bali, Nusa Tenggara and Timor Leste. Sulawesi is also known as the Wallace region which is the boundary between East Malesia and West Malesia (Kartawinata 2013). Eastern Malesia zone generally contains fewer species, and its structure is not as complex as vegetation in the West Malesia region such as Kalimantan and Sumatra. Lowland dipterocarp forests in western Malesia have generally main canopy layer at a height of $30-45 \mathrm{~m}$ with emergent trees up to $60 \mathrm{~m}$ tall (Kartawinata 2013). The more complex vegetation structure has created an environment suitable for the growth of various species of plants (Whitmore 1986, Kartawinata 2013). In one hectare, hundreds of tree species with $\mathrm{dbh} \geq 10 \mathrm{~cm}$ can be found in various forest plots in Kalimantan and Sumatra (Riswan 1987; Abdulhadi et al. 1989; Kartawinata et al. 2004; Sambas and Siregar 2004; Simbolon et al. 2005; Yusuf 2005; Kartawinata 2013). The highest tree species richness in Kalimantan was recorded in lowland forest in Malinau, East Kalimantan which contains
205 tree species in one hectare (Sheil et al. 2010).In Sumatra, the highest tree species richness was recorded in Batang Gadis National Park, North Sumatra with 184 tree species in one hectare (Kartawinata et al. 2004). Even in the Batang Toru forest, North Sumatra, there were 155 species of trees found within only 0.28 ha plot (Sambas, Siregar 2017). The richness of tree species increases when the extent of sample plots is expanded. The dipterocarp lowland forest plots in Samboja East Kalimantan contained 441 tree species in 5 ha plot and increased to 550 species when the plot was expanded to 10.5 ha (Kartawinata 2010).

Various studies showed that in Sulawesi, the richness of tree species in the 0.5 ha plot only ranges 40-60 species (Mansur 2005; Purwaningsih 2006). Several other studies used a separate plot method with a total area of less than 1 ha, the number of species recorded only 45-98 tree species (Purwaningsih and Yusuf 2005; Irawan 2011; Suryawan et al. 2013; Rukmi 2014). Another study in Bogani Nani Wartabone National Park recorded 132 species of trees in four separate plots with total area of 0.86 ha. However, if each plots is sampled separately with an area of 0.20-0.26 ha, there were only 33-61 tree species found per plot (Polosakan and Siregar 2001). The methodology and size of the sample plot influence number of species recorded (Sambas and Siregar 2017). Generally, separating plots with a wider size of the sampled area can increase species richness. This is because habitat variations in separate plots tend to be larger than single plot since tropical forests are known to vary greatly from place to place (Kartawinata 2013). The ability of species to occupy an area depends on its ability to adapt optimally to abiotic and biotic factors (Krebs 1994). Besides phenology, dispersal and mortality also influence the structure and composition of vegetation (Kimmins 1987).

The area of research plots in Kalimantan and Sumatra is far greater than in Sulawesi. This bias will affect the number of species obtained, yet comparing the structure of vegetation is still beneficial. The results of previous studies at 10 locations in Sulawesi (Mansur 2005; Purwaningsih and Yusuf 2005; Purwaningsih 2006; Suryawan et al. 2013; Wahyuni and Mokodompit 2016) may describe current forest condition in Sulawesi. Tree densities in these ten locations range from 244 to $813 \mathrm{ha}^{-1}$ trees with an average of 468 trees $\mathrm{ha}^{-1}$. Basal area ranges from 16.32 to $34.80 \mathrm{~m}^{2}$ $\mathrm{ha}^{-1}$ with an average of $26.11 \mathrm{~m}^{2} \mathrm{ha}^{-1}$. On the other hand, previous studies at 16 locations in Kalimantan (Kartawinata et al. 1981; Riswan 1987; Yusuf 2003; Yusuf 2005; Simbolon 2005; Simbolon et al. 2005; Sidiyasa 2009; Istomo and Afnani 2014) show that tree densities range from 313 to $787 \mathrm{ha}^{-1}$ trees with an average of $465 \mathrm{ha}^{-}$ 1 trees, while ranges of basal area are between 13.6 and $59.5 \mathrm{~m}^{2} \mathrm{ha}^{-1}$ with an average of $27.65 \mathrm{~m}^{2} \mathrm{ha}^{-1}$. In Sumatra, research results from 7 locations (Abdulhadi et al. 1989; Sambas and Siregar 1999; Kartawinata et al. 2004; Sambas and Siregar 1999, 2004; Samsoedin and Heriyanto 2010) show that tree densities range from 453 to687 ha-1 trees with an average of $556 \mathrm{ha}^{-1}$ trees, while the range of basal area are 22.9-40.9 $\mathrm{m}^{2} \mathrm{ha}^{-1}$ with an average of $30.74 \mathrm{~m}^{2} \mathrm{ha}^{-1}$. Based on those references, it can be seen that tree density 
and basal area in Sulawesi are not much different from Kalimantan, but is lower compared to Sumatra.

Tree densities in this study vary between 164 and 721 trees $\mathrm{ha}^{-1}$ with an average of 420 trees $\mathrm{ha}^{-1}$. Bukaka with density of 721 trees ha $^{-1}$ is classified as high compared to the average tree density in Sulawesi, Kalimantan and Sumatra. If compared per location, tree density in Bukaka is lower than that found on Wawonii Island, Southeast Sulawesi with 813 trees ha $^{-1}$ (Purwaningsih 2006), and Bentuang Karimun National Park in West Kalimantan with 787 trees $\mathrm{ha}^{-1}$ (Partomihardjo et al. 1999 in Yusuf 2005). The density of trees in Lambak (482 trees ha ${ }^{-1}$ ) is slightly higher than the average tree density in Sulawesi and Kalimantan, and lower than in Sumatra. The density of trees in Basaan (439 trees ha-1) is higher with the average tree density in Sulawesi, but lower than in Kalimantan and Sumatra. Whereas tree density in Garini (292 trees ha-1) and Soyowan (164 trees ha $\mathrm{ha}^{-1}$ ) is considered low if compared to the average tree density in Sulawesi, Kalimantan and Sumatra.

Basal area in five studied areas ranges from 20.98 to $53.59 \mathrm{~m}^{2} \mathrm{ha}^{-1}$ with an average of $36.4 \mathrm{~m}^{2} \mathrm{ha}^{-1}$. Garini has the highest basal area $\left(53.59 \mathrm{~m}^{2} \mathrm{ha}^{-1}\right)$, followed by Basaan $\left(51.62 \mathrm{~m}^{2} \mathrm{ha}^{-1}\right)$, which are above the average basal area of forest plots in Sulawesi, Kalimantan and Sumatra. Basal area in these two locations is rivaled by Bentuang Karimun National Park forest plot in West Kalimantan with 59.52 $\mathrm{m}^{2}$ ha $^{-1}$ (Partomihardjo et al. 1999 In: Yusuf 2005). Basal area in Lambak $\left(30.74 \mathrm{~m}^{2} \mathrm{ha}^{-1}\right)$ is relatively similar with the average basal area of forest plots in Sulawesi, Kalimantan and Sumatra, but basal area in Bukaka $\left(20.98 \mathrm{~m}^{2} \mathrm{ha}^{-1}\right)$ and Soyowan $\left(24.13 \mathrm{~m}^{2} \mathrm{ha}^{-1}\right)$ are classified as low.

Many factors influence the density and basal area of trees in a forest area. The most prominent factors are habitat quality and human activities (Mani and Parthasarathy 2009). Disturbances to forests such as logging and fires can reduce the population and basal area and ultimately reduce species richness (Simbolon 2005, Gibson et al. 2011).

The patches of forest in the studied areas are quite susceptible to disturbances, especially in Bukaka, Lambak, Soyowan and Basaan, as they are surrounded by agricultural areas, mixed gardens and settlements. Soyowan forest, which has low tree density and basal area, seems to face more severe threat because of its location close to settlement. In this forest, there is H. longipetiolata which is classified as vulnerable to extinction (Vulnerable D2 ver 2.3) based on the IUCN red list (IUCN 2018). Bukaka also faces the same problem. Although it is relatively far from settlement, the location is on the side of road and side by side with people's gardens, causing risk for disturbance. In Bukaka, there is endangered species $L$. dilleniifolia (Endangered B1 + 2ce ver 2.3) based on the IUCN red list (IUCN 2018). Lambak forest is relatively far from settlement, but it is surrounded by people's gardens. Despite vulnerable to disturbances, condition of Lambak forest is still relatively good in terms of the tree density and basal area. There are two species of trees categorized as vulnerable to extinction (Vulnerable A1c ver 2.3 ), namely A. cumingiana and Saurauia leucocarpa. In Basaan, the location is the closest to settlement and on the edge of provincial road, but it is relatively protected. This is due to the condition of rocky land (limestone) with thin soil solum which is not suitable for agriculture. In addition, Basaan forest also contains springs that are widely used by the community. No endangered tree species is found in Basaan. Tree density in Garini is relatively low, but it has large basal area. Garini forest seems to be in climax stage with emergent trees up to $35 \mathrm{~m}$ tall including $B$. racemose, $C$. odorata, $D$. dao and $O$. sumatrana. Forest conditions are still very good without any traces of logging. There is one species of Dipterocarpaceae, namely P. malaanonan which is under endangered category (Critically Endangered A1cd ver 2.3) based on the IUCN red list (IUCN 2018). Need to be aware, considering that on the edge of the forest there is a simple camp with wood piles that shows logging activities have begun to penetrate into this area.

It can be concluded that the patches of forest studied have relatively large variations in tree species and are thought to be a result of geological variations. Wealth of tree species is lower than forest plots in the West Malesia region (Kalimantan and Sumatra), but the vegetation structure reflected in the density of individuals and their basal area is relatively not much different. The variation is greatly influenced by the level of disturbance in the forest. The patches of forest were recorded as still containing tree species classified as endangered based on the IUCN red list.

\section{ACKNOWLEDGMENTS}

Acknowledgments are conveyed to Research Center for Plant Conservation and Botanic Gardens (formerly Center for Plant Conservation, Bogor Botanic Garden), Indonesian Institute of Sciences (LIPI) for its funding support. We thank the Government of Southeast Minahasa District and all those who assisted this research.

\section{REFERENCES}

Abdulhadi R, Mirmanto E, Yusuf R. 1989. Forest structure and composition of Dipterocarpaceae in Ketambe, Gunung Leuser National Park, Aceh. Ekologi Indonesia 1 (2): 29-36. [Indonesian]

Abdulhadi R, Yusuf R, Kartawinata K. 1991. A riverine tropical rain forest in Ketambe, Gunung Leuser National Park, Sumatra, Indonesia. In: Soerianegara I, Tjitrosomo SS, Umaly RC, Umboh I (eds). Proceedings of the fourth round-table conference on dipterocarps. Biotrop Special Publication No. 41: 247-255.

Aigbe HI, Omokhua GE. 2014. Modeling diameter distribution of the tropical rainforest in Oban Forest Reserve. Journal of Environment and Ecology 5 (2): 130-143.

Arumingtyas L. 2018. Indonesian deforestation 2017 down, definition still debate. Mongabay. Jakarta. https://www.mongabay.co.id/2018/01/29/deforestasi-indonesia-2017turun-definisi-masih-perdebatan/[Indonesian]

Climate-Data.Org. 2018. https://id.climate-data.org/

Corlett RT. 2005. Vegetation. In: Gupta A (ed.) The physical geography of Southeast Asia. Oxford University Press, Oxford: 105-119

Gentry AH. 1988. Changes in plant community diversity and floristic composition on environmental and geographical gradients. Annals of the Missouri Botanical Garden 75 (1): 1-34.

Gibson L, Lee TM, Koh LP, Brook BW, Gardner TA, Barlow J, Peres CA, Bradshaw CJ, Laurance WF, Lovejoy TE, Sodhi NS. 2011. 
Primary forests are irreplaceable for sustaining tropical biodiversity. Nature 478 (7369): 378-381.

Global Invasive Species Database. 2018. Piper aduncum. http://issg.org/database/species/ecology.asp?si=332\&fr=1\&sts=\&lang $=\mathrm{EN}$

Grubb PJ. 1987. Global trends species-richness in terrestrial vegetation: a view from the northern hemisphere. In: Gee JMR, Giller PS (eds) Organisation of communities, past and present. Symposium of British Ecological Society 27: 99-118. Blackwell Scientific Publications, Oxford.

Forest Watch Indonesia. 2011. Portrait of the state of Indonesian forests for the 2002-2009 period. 1st edition. [Indonesian]

Gaveau DLA, Sheil D, Yaen H, Salim MA, Arjasakusuma S, Ancrenaz M, Pacheco P, Meijaard E. 2016. Rapid conversions and avoided deforestation: examining four decades of industrial plantation expansion in Borneo. Scientific Reports. 6:32017. DOI: $10.1038 /$ srep32017

Gaveau DLA, Locatelli B, Salim MA, Yaen H, Pacheco P, Sheil D. 2018. Rise and fall of forest loss and industrial plantations in Borneo (20002017). Policy Perspective. Conservation Letters. A Journal of The Society for Conservation Biology. DOI: 10.1111/conl.12622.

Hansen MC, Potapov PV, Moore R, Hancher M, Turubanova SA, Tyukavina A, Thau D, Stehman SV, Goetz SJ, Loveland TR, Kommareddy A, Egorov A, Chini L, Justice CO, Townshend JRG. 2013. High-resolution global paps of 21st-century forest cover change. Science 342 (6160): 850-853.

Hartshorn, GS. 1980. Neotropical forest dynamics. Tropical succession. Biotropica, Suppl. 12 (2): 20-30.

Hammer, Ø. 2014. PAST-Paleontological Statistics version 3.04. Natura History Museum, University of Oslo, Oslo, Norway.

Irawan A. 2011. Linkages in structure and composition of vegetation to the presence of anoa in the Mount Poniki complex, Bogani Nani Wartabone National Park, North Sulawesi. Info BPK Manado 1 (1), November 2011. [Indonesian]

Istomo, Afnani M. 2014. Potential and distribution of meranti species (Shorea spp.) in protected areas of PT. Wana Hijau Pesaguan, West Kalimantan. Jurnal Silvikultur Tropika 5 (3):196-205. [Indonesia]

IUCN. 2018. The IUCN Red List of Threatened Species. http://www.iucnredlist.org/

Kalangi JI, Rombang J, Pollo HN. 2009. Hydrological Analysis and Modeling in Drain Diversion Areas PT. NMR and Ratatotok river. Agriculture Faculty, UNSRAT: 14-22. [Indonesian]

Kartawinata K. 2010. Two centuries reveal the richness of Indonesia's flora and ecosystem. Sarwono Prawirohardjo Memorial Lecture X LIPI. 23 August 2013. Jakarta. [Indonesian]

Kartawinata K. 2013. Indonesia's natural ecosystem diversity. A short phrase with a photo and picture presentation. LIPI Press. Yayasan Pustaka Obor Indonesia. Jakarta [Indonesian]

Kartawinata K, Abdulhadi R, Partomihardjo T. 1981. Composition and structure of a lowland dipterocarp forest at Wanariset, Eas Kalimantan. Malaysian Forester 44 (2-3): 397-406

Kartawinata K, Samsoedin I, Heriyanto M, Afriastini JJ. 2004. A tree species inventory in a one-hectare plot at the Batang Gadis National Park, North Sumatra, Indonesia. Reinwardtia 12 (2): 145-157.

Ministry of Environment and Forestry. 2016. Statistics of Forestry planology and environmental management in 2016. Directorate General of Forestry Planning and Environmental Management. Ministry of Environment and Forestry. Jakarta. http://pktl.menlhk.go.id/asset/action.php?action=openfile\&filename= 20180417120111.pdf [Indonesian]

Kimmins JP. 1987. Forest Ecology. New York: Macmillan Publishing Co.

Knight RS, Crowe TM, Siegfried WR. 1982. Distribution and species richness of trees in southern Africa. South African Journal of Botany 48: 455-480.

Krebs CJ. 1994. Ecology. The experimental analysis of distribution and abundance. New York: Addison-Wesley Educational Publishers.

Mani S, Parthasarathy N. 2009. Tree population and above-ground biomass changes in two disturbed tropical dry evergreen forests of peninsular India. Trop Ecol 50 (2): 249-258.

Mansur M. 2005. Analysis of forest vegetation around Mount Wani, North Buton Wildlife Reserve, Southeast Sulawesi. Jurnal Teknologi Lingkungan P3TL-BPPT 6 (3): 469-476. [Indonesian]

Mori SA, Boom AM, de Carvalino AM, dos Santos TS. 1983. Ecological importance of Myrtaceae in an Eastern Brazilian wet forest. Biotropica 15 (1): 68-78
Mueller-Dombois D, Ellenberg H. 1974. Aims and methods of vegetation ecology. John Wiley \& Sons, New York.

O'Brien, E.M. 1993. Climatic gradients in woody plant species richness: towards an explanation based on an analysis of Southern Africa's woody flora. Journal of Biogeography 20 (2): 181-198.

Pausas JG, Austin MP. 2001. Patterns of plant species richness in relation to different environments: An appraisal. Journal of Vegetation Science 12: 153-166.

Pausas JG, Carreras J. 1995. The effect of bedrock type, temperature and moisture on species richness of Pyrenean Scots pine (Pinus sylvestris L.) forests. Vegetatio 116 (1): 85-92.

Polosakan R, Siregar M. 2001. Analysis of tree vegetation in the forest of Mount Kabela cluster Bogani Nani Wartabone National Park-North Sulawesi. Ekologi Indonesia 3 (1): 37-50. [Indonesian]

Priatna D, Kartawinata K, Abdulhadi R. 2006. Recovery of a lowland dipterocarp forest twenty-two years after selective logging at Sekundur, Gunung Leuser National Park, North Sumatra, Indonesia. Reinwardtia 12 (3): 237-255.

Proctor J, Anderson JM, Chai P, Vallack HW. 1983. Ecological studies in four contrasting lowland rain forests in Gunung Mulu National Park, Serawak. I. Forest environment, structure and floristics. J Ecol 71: 237-260.

Purwaningsih. 2006. Analysis of forest vegetation at several altitudes at Mount Wawouwai, Wawonii Island, Southeast Sulawesi. Biodiversitas 7 (1): 49-54. [Indonesian]

Purwaningsih, Yusuf R. 2005. Species composition and forest vegetation structure in Pakuli Region, Lore Lindu National Park, Central Sulawesi. Biodiversitas 6 (2): 123-128. [Indonesian]

Richerson PJ, Lum KL. 1980. Patterns of species diversity in California: relations to weather and topography. American Naturalist 116 (4): 504-536.

Riswan S. 1987. Structure and floristic composition of a mixed dipterocarp forest at Lempake, East Kalimantan. In: Kostermans AJGH (ed). Proceedings of the third-round table conference on dipterocarps, UNESCO, Jakarta: 435-457.

Rukmi. 2014. Vegetation composition in ebony forest in the Tambarana forest group in Poso Pesisir Utara Subdistrict, Poso Regency, Central Sulawesi. Warta Rimba 2 (2): 158-165. [Indonesian]

Sambas EN, Siregar M. 1999. Flora composition of the forests of Mount Muncung, Singkep, Riau. Bulletin Kebun Raya Indonesia 9 (1): 7-17. [Indonesia]

Sambas EN, Siregar M. 2004. Flora of Alas River Bank, Ketambe, Gunung Leuser National Park. BioSmart 6 (1): 33-38.

Sambas EN, Siregar M. 2017. Floristic and forest structural study in Batangtoru Watershed, North Sumatra. Jurnal Biologi Indonesia 13 (1): 21-31

Samsoedin I, Heriyanto NM. 2010. Structure and composition of illegal logged-over forests in the Sei Lepan forest group, Sei Serdang, Gunung Leuser National Park, North Sumatera. Jurnal Penelitian Hutan dan Konservasi Alam 7 (3): 299-314. [Indonesian]

Sheil D, Kartawinata K, Samsoedin I, Priyadi H, Afriastini JJ. 2010. The lowland forest tree community in Malinau, Kalimantan (Indonesian Borneo): results from a one-hectare plot. Plant Ecology and Diversity 3: $1-8$.

Sidiyasa K. 2009. Structure and composition of stands and their diversity in the Sungai Wain Protection Forest in Balikpapan, East Kalimantan. Jurnal Penelitian Hutan dan Konservasi Alam 6 (1): 79-93. [Indonesian]

Simbolon H. 2005. Dynamics of mixed Dipterocarp forest in Wanariset, Semboja, East Kalimantan after three fires in 1980-2003. Biodiversitas 6 (2): 133-137. [Indonesian]

Simbolon H, Siregar M, Wakiyama S, Sukigara N, Abe Y, Shimizu H. 2005. Impacts of forest fires on tree diversity in tropical rain forest of East Kalimantan, Indonesia. Phyton 45 (4): 551-559.

Siregar M. 2017. Spatial distribution of abundant tree species at a mixed dipterocarps forest in Bukit Bangkirai, East Kalimantan three years after long drought and forest fire. In: Setyawan AD, Sugiyarto, Pitoyo A, Sutomo, Widiastuti A, Windarsih G, Supatmi (eds). Prosiding Seminar Nasional Masyarakat Biodiversitas Indonesia 3 (2): 246-251.

Suryawan A, Kinho J, Mayasari A. 2013. Structure and distribution of Euphorbiaceae family in Tangkoko Nature Reserve, Bitung, North Sulawesi. Info BPK Manado 3 (2): 89-101. [Indonesian]

Suwardi AB, Mukhtar E, Syamsuardi. 2013. Composition of species and carbon stocks in lowland tropical forests, Ulu Gadut, West Sumatera. Berita Biologi 12 (2): 169-176. [Indonesian] 
Tilman D. 1988. Plant strategies and the structure and dynamics of plant communities. Princeton University Press, Princeton, New Jersey.

Tothmeresz B. 2013. Diversity. University of Debrecen, Debrecen, Hungary.

Toure D, Ge J. 2014. The response of plant species diversity to the interrelationships between soil and environmental factors in the limestone forests of Southwest China. Journal of Environment and Earth Science 4 (8): 105-122

Wahyuni NI, Mokodompit HS. 2016. Structure, composition and diversity of tree species in the Production Forest of Inobonto Poigar I, KPHP Poigar, North Sulawesi. Jurnal Wasian 3 (1):45-50. [Indonesian]
Whitmore TC. 1986. Tropical rain forests of the far east, ${ }^{2 n d}$ ed. Oxord University Press, Oxford.

Wright SJ. 1992. Seasonal drought, soil fertility and species density of tropical forest plant communities. Trends in Ecology and Evolution 7 (8): 260-263.

Yusuf R. 2003. Ecological research on tree species in the Bulungan forest area, Bulungan Regency-East Kalimantan. Berita Biologi 6 (6): 767780. [Indonesian]

Yusuf R. 2005. Vegetation analysis of mixed Dipterocarpaceae forests in Kayan Mentarang National Park, East Kalimantan. Biosfera 22 (2): 54-66. [Indonesian] 